\title{
Soil Properties as Affected by Soil Conservation Practices and Soil Depths in Uwite Watershed, Hadero Tunto District, Southern Ethiopia
}

\author{
Mulugeta Hadaro ${ }^{(D},{ }^{1}$ Tuma Ayele, ${ }^{2}$ Sharma Parshotam Datt, ${ }^{3}$ and Rahel Teshome ${ }^{3}$ \\ ${ }^{1}$ Department of Plant Sciences, College of Agriculture and Natural Resources, Mizan-Tepi University, Addis Ababa, Ethiopia \\ ${ }^{2}$ Arba Minch Agricultural Research Center, Addis Ababa, Ethiopia \\ ${ }^{3}$ Department of Plant Sciences, College of Agricultural Sciences, Arba Minch University, Addis Ababa, Ethiopia
}

Correspondence should be addressed to Mulugeta Hadaro; mulugetahadaro@mtu.edu.et

Received 19 January 2021; Revised 14 June 2021; Accepted 9 July 2021; Published 21 July 2021

Academic Editor: Teodoro M. Miano

Copyright (c) 2021 Mulugeta Hadaro et al. This is an open access article distributed under the Creative Commons Attribution License, which permits unrestricted use, distribution, and reproduction in any medium, provided the original work is properly cited.

\begin{abstract}
Soil is a precious natural resource, forming the basis for sustained ecosystem services for the mankind. Its degradation due to the ever-increasing anthropogenic influence is, however, threatening food security and quality of the environment in many regions. The present investigation was, therefore, undertaken with an objective of assessing the effect of soil and water conservation practices of soil bund and Fanya juu terrace compared to no conservation practice on cultivated soils of Uwite watershed in Hadero Tunto District, southern Ethiopia. Soil sampling sites were selected both from the farm fields, where soil conservation structures were raised for the last 10 years, and from fields where there was no conservation practice. A total of eighteen composite soil samples ( 3 conservation practices $\times 2$ depths, $0-15$ and $15-30 \mathrm{~cm}, \times 3$ replicates) were collected and analyzed for different physical and chemical soil parameters. The results were subjected to analysis of variance using the General Linear Model of twoway ANOVA by RCBD with factorial arrangement using SAS software. Both practices, statistically similar to each other, indicated significant improvement in soil parameters compared to no conservation practice in higher content of clay, lower bulk density, higher total porosity, higher moisture content, higher $\mathrm{pH}$, higher soil organic matter, higher percent base saturation, higher cation exchange capacity, and higher amounts of macro- ( $\mathrm{N}, \mathrm{P}, \mathrm{K}, \mathrm{Ca}, \mathrm{Mg}$, and $\mathrm{S})$ and micronutrients $(\mathrm{Fe}, \mathrm{Zn}$, and $\mathrm{Cu})$. The surface soil layer $(0-15 \mathrm{~cm})$ was significantly superior to the subsurface layer $(15-30 \mathrm{~cm})$ in most of these soil parameters. Both practices of soil bund and Fanya juu terrace merit their continuation on the existing lands and upscaling to other degraded areas for sustained land productivity and socioeconomic-environmental stability in the region
\end{abstract}

\section{Introduction}

Soil is an invaluable natural resource, forming the basis for food and environmental, social, and economic security for the mankind. Its improper use and overuse result in land degradation, causing many on- and off-site damages like decline in soil fertility and crop productivity, disruption in hydrological functioning of watersheds, increased incidence of droughts and floods, shrinking water supplies, increased sedimentation of water bodies and rivers, vulnerability to climate change, and deterioration in the socioeconomic status of people [1-3]. The well-managed healthy soils, on the other hand, are least prone to either of these problems and ensure sustained ecosystem services [4].

There are estimates that $75 \%$ of the land worldwide is degraded [5] and 5 to 6 million hectares of arable land are being lost annually to severe degradation [6]. Needless to say, the severely degraded areas bereft of natural capital, social capital, and economic capital are home to the most disadvantaged people, suffering from hunger, malnutrition, and poverty [7-9].

To fight poverty and secure human well-being, the United Nations (UN) has adopted 17 Sustainable Development Goals (SDGs) in 1975, embracing sustainable use of 
our planet's resources [10]. The sustainable development here implies the development that meets the needs of the present, while safeguarding earth's life-support system on which the welfare of current and future generations depends [11]. A sound soil-water system is essential for achieving most of these SDGs [10]. Achieving SDG 15.3, entailing Land Degradation Neutrality (LDN) and land restoration, by 2030 (the deadline for realizing the SDGs) would, however, require a holistic approach that integrates environmental, social, and economic imperatives in different agricultural settings [10]. Further, the transition towards nature-based integrated solutions would, obviously, call for new element of landscape and land-use planning and management.

The problem of land degradation associated with soil erosion by water is severe in Ethiopia [3,12]. A number of natural and anthropogenic factors that contribute to accelerated soil erosion are large-scale deforestation, uncontrolled grazing by livestock, high-intensity rainstorms, cultivation on sloping lands, lack of soil conservation practices, and low level of soil management [12-15]. The annual soil loss from landmass has been estimated to be 1.5 billion metric tons, of which $50 \%$ occurred on croplands, especially in highlands [16-18]. The cultivated lands on steep slopes are reported to have erosion rates of 20 to $237 \mathrm{t} \mathrm{ha}^{-1}$ [19-22] in severely eroded areas, almost 10-20 times the rate of soil formation $\left(\sim 10-12 \mathrm{tha}^{-1} \mathrm{year}^{-1}\right)$. The on-site damages by soil erosion are manifest in poor soil fertility [23-25] and reduced crop yields $[26,27]$. The average cereal productivity at national level is still less than $2 \mathrm{tha}^{-1}$. The direct losses of productivity from land degradation in the country may be put minimally at 3 percent of agricultural gross domestic product (GDP) [28].

Agriculture is the mainstay of Ethiopian economy, contributing approximately $41 \%$ of the GDP, $84 \%$ of the total exports, and $80 \%$ of the employment [29-32]. The agriculture-led industrialization is envisaged to provide a fillip to Ethiopian economy in the near future, with the development of integrated agroindustrial parks in different agroecologies [33]. The continued land degradation, however, poses a greater challenge to the agricultural sector and realization of development goals.

To halt soil degradation and restore the affected lands, the Ethiopian Government had launched several soil conservation programmes in the past with the help of international aid and development agencies [34] involving NGOs and local people. The different programs under Food for Work Program comprised Land Leveling Programme (LLP), Sustainable Land Management (SLM), United Nations Development Program (UNDP), Productive Safety Net Program (PSNP), etc. One such programme using mechanical soil conservation practices like soil bund and Fanya juu terrace was introduced in the Uwite watershed of Hadero Tunto District under the auspices of Inter Aide France and Productive Safety Net Program (PSNP). Both practices are acknowledged to be more effective for erosion control on slopes than strip cropping and contour farming, as these divide the slope into discrete segments and reduce the gradients of the cultivated parts [35]. The 20-year-old SWCPs (soil bund and Fanya juu ridge) have been found to effect a $2.7 \%$ slope reduction on average because of the trapped sediment in the Minizr catchment, northwest Ethiopia [18]. Fanya juu is a soil and water conservation structure that has been widely used in Africa especially in Kenya, Tanzania, Uganda, and Ethiopia. The structure is an embankment made of soil and/or stone with a basin in the lower part [36]. The soil and rainwater are conserved between the Fanya juu bunds. The land between embankments/bunds levels off and takes the shape of a bench terrace. If properly maintained, the structure would eventually lead to the development of bench terraces in the field over a period of time [37]. The development would create better growing conditions for the crop, both immediately, because of an increase in the amount of moisture available, and in the long term, because the soil is conserved.

The soil and water conservation practices (SWCPs) already in place for many years might have produced positive effects on soil physical and chemical characteristics and overall productivity of the lands. The evaluation may, therefore, guide us on continuance of soil conservation practices as such, their midway modifications, or alternative land management practices are compatible with the local socioeconomic-environmental imperatives. Monitoring and evaluation of soil conservation activities at regular intervals is one of the essential components of watershed management programs. This has great relevance for Ethiopia, where about $18 \%$ the rainfed croplands have so far been treated with SWCPs and $60 \%$ (nearly 12 million ha) still need to be covered [38].

Many recent studies in Ethiopia in different parts of the country have confirmed the positive impacts of SWCPs on soil properties and crop yields [39-44]. The questionnairebased farmers' survey has also indicated that majority of the farmers (83.3\%) in Mawula Watershed, Loma District, southern Ethiopia, had perceived the SWCPs as useful and adopted them [44]. There are also reports of either negative or little impact of SWCPs on soil properties in some areas [27]. The farmers have dismantled the structures on the notion that SWCPs were simply occupying the cultivated area without accruing any yield benefits. However, we need to thoroughly establish the reasons for such failures before undermining the importance of SWCPs in ameliorating soil environment and enhancing crop yields. For the present, we need to continue with our concerted efforts of establishing the benefits of SWCPs in different agroecologies and providing the required protection to the degraded lands.

The present study was, therefore, carried out in degraded Uwite watershed of Hadero Tunto District, southern Ethiopia, to evaluate the effect of soil bund and Fanya Juu terrace on improvement of soil properties governing soil fertility and productivity.

\section{Materials and Methods}

2.1. General Description of Area. The study was conducted in the Uwite watershed located in Hadero Tunto Zuria woreda, Kembata Tembaro zone, Southern Nations, Nationalities, and Peoples' Regional State (SNNPRS). Geographically, the 
area lies between coordinates of $7^{\circ} 12^{\prime} 30^{\prime \prime}$ and $7^{\circ} 14^{\prime} 30^{\prime \prime} \mathrm{N}$ latitude and $37^{\circ} 39^{\prime} 30^{\prime \prime}$ and $37^{\circ} 42^{\prime} 0^{\prime \prime} \mathrm{E}$ longitude (Figure 1). The watershed covered an area of 295.5 ha and had over 425 households. The woreda is relatively densely populated with about 502 people per $\mathrm{km}^{2}$ and shortage of land has contributed to overutilization of the available land and a decline in soil fertility. There are frequent dry spells and declining livestock ownership, making the woreda an area of acute and chronic food insecurity. The area has been looking for regular food aids in recent years [45].

2.1.1. Topography and Climate. The altitude of the watershed ranges from 1741 to $1850 \mathrm{~m}$ above sea level. The landform consists of 5\% plain, 30\% plateau, and $65 \%$ sloping and rugged terrain. According to report of District Agriculture and Natural Resources Development Office, the watershed had $32.5 \%$ area under $15-30 \%$ slope, $57 \%$ under $7-15 \%$ slope and $10.5 \%$ under foothill gentle slopes. The mean maximum and minimum temperatures were $25.6^{\circ} \mathrm{C}$ and $14.48^{\circ} \mathrm{C}$, respectively. The Hadero Tunto district has two major agroecological zones, the Dega and Wyna Dega, covering 38.46\% and $61.54 \%$ area, respectively. The annual rainfall of the woreda is $1200-1500 \mathrm{~mm}$. Agricultural activity is planned during the Belg rainy season (between March and May) and the summer rainy season (falling between June and September).

2.1.2. Land Use and Vegetation. According to woreda Agriculture and Natural Resources Development Office report of 2019/20, the cultivated land accounts for an average of about $72 \%$ and the grassland, forest lands, and closure sites together account for about $18 \%$ of the total area of the watershed. The remaining $10 \%$ of the total area of the watershed constituted settlements and so on. A rural household had an average of 0.6 ha of land, compared to the national and SNNPRS averages of 1.01 and $0.89 \mathrm{ha}$, respectively. Cultivation is done even on steep slopes (>20\%). The catchment is suitable for a large variety of crops, such as enset, maize, teff, and pulses. The major crops grown during the main rainy season are maize, teff, haricot beans, sweet potato, and field pea. The haricot bean and sweet potato are the dominant small rainy season crops. The natural vegetation of the watershed comprised trees, bushes, and grasses. The trees occurring in the area belong to plantation forests, including species such as Juniperus procera and Olea africana. Bushes and shrubs are found on steep slopes and along river valleys. Meadow grasses and species of Lobelia are found along the edges of watershed. Currently, refilling or replantation strategy is being implemented in the study area by Woreda Agriculture and Natural Resources Development Office. Soil conservation practices like soil bund and Fanya juu terraces have been introduced on cultivated farmlands and communal lands in the watershed. The conservation measures are implemented for the last 10 years with the support of Inter Aide France, Productive Safety Net programs (PSNP), and mass mobilization of the community.
2.1.3. Soil Type. The soil types of the study area are dystric nitisols, chromic luvisols, and pellic vertisols (Figure 2). The nitisols occupy large area in the watershed.

2.2. Site Selection and Soil Sampling. The Uwite watershed, one of the 59 community micro watersheds in Hadero Tunto Zuria woreda, was selected purposely for its specific experience with implementation of SWCPs. The soil sampling sites were selected both from the farm fields where soil conservation structures (soil bund and Fanya juu terrace) were practiced, and from fields where there was no conservation practice, by random sampling method. The soil samples were drawn by auger for each soil conservation practice from the middle of the bench between the structures at two depths $(0-15$ and $15-30 \mathrm{~cm})$. A total of 18 composite soil samples ( 3 conservation practices $\times 2$ soil depths $\times 3$ replications), each formed on 10 subsamples, were collected in February 2019. The soil samples were brought to the laboratory, air-dried, mixed well, and passed through a $2 \mathrm{~mm}$ sieve for the analyses of soil properties. Soil core samples from the two depths for bulk density determination were taken with a sharp-edged steel cylinder forced manually into the soil. Global Positioning System (GPS) and clinometer were used to know the geographical location and slope of the sampling sites, respectively.

2.3. Soil Analysis. Most of soil physical and chemical analyses were carried out at Wolaita Sodo Soil Testing Laboratory of the SNNPR's Agriculture Bureau, while exchangeable basic cations, available sulphur, and micronutrients were analyzed at Arba Minch University Chemistry Laboratory. Standard laboratory procedures were followed for the analyses of the selected physicochemical properties. The particle size distribution was determined by the Boycouos hydrometric method [46]. Soil bulk density was determined using undisturbed core samples as described by Black [47]. Total porosity was calculated using general equation relating bulk density and particle density. Soil moisture content was expressed on mass basis $(\mathrm{Mw})$. The $\mathrm{pH}$ of the soil was measured potentiometrically using a digital $\mathrm{pH}$ meter in the supernatant suspension of $1: 2.5$ soil to water ratio [48]. The Walkley and Black wet digestion method [49] was used to determine the soil organic carbon content (SOC). Soil organic matter was calculated by multiplying soil organic carbon by a factor of 1.724 . Total $\mathrm{N}$ was analyzed using the Kjeldahl digestion method as described by Bremner and Mulvaney [50]. Soil available phosphorus was determined by Olsen et al.'s method [51]. Available sulphur was determined in the soil extract by the turbidity method (52). Exchangeable bases (Ca, $\mathrm{Mg}, \mathrm{K}$, and $\mathrm{Na}$ ) were determined after extracting the soil samples with neutral $1 \mathrm{~N}$ ammonium acetate. While exchangeable $\mathrm{Ca}$ and $\mathrm{Mg}$ in the extracts were analyzed using atomic absorption spectrophotometer, exchangeable $\mathrm{Na}$ and $\mathrm{K}$ were analyzed by flame photometer. The cation exchange capacity (CEC) was determined after extracting the soil samples with $1 \mathrm{~N}$ $\mathrm{NH} 4 \mathrm{OAc}$ at $\mathrm{pH} 7.0$ and distilling ammonium displaced by leaching with $\mathrm{NaCl}$ solution [52]. Percent base saturation 


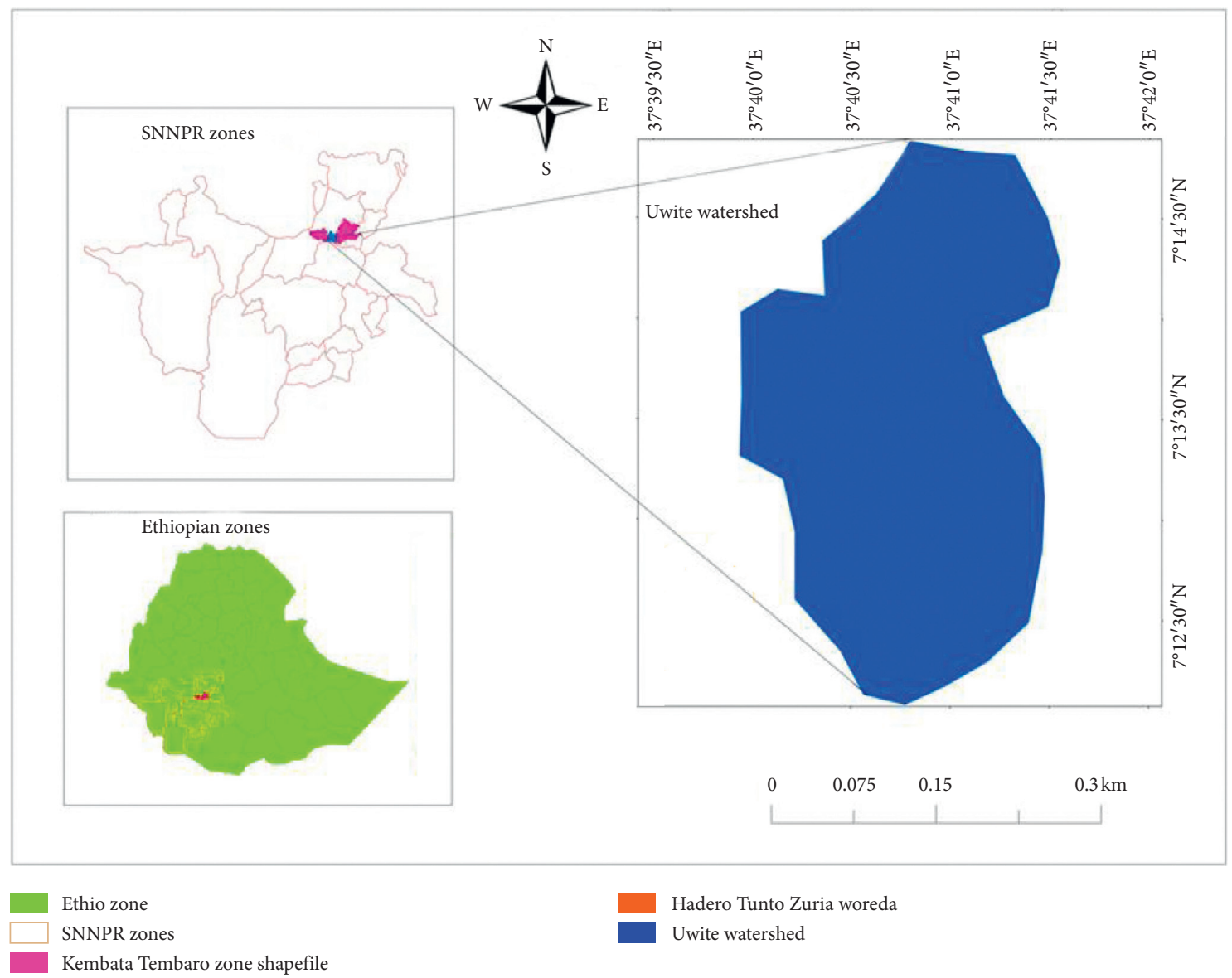

Figure 1: Map of the study area.

(PBS) was calculated as the ratio of sum of the base forming cations ( $\mathrm{Ca}, \mathrm{Mg}, \mathrm{K}$, and $\mathrm{Na}$ ) to $\mathrm{CEC}$ of the soil and multiplied by 100 . Available $\mathrm{Fe}, \mathrm{Mn}, \mathrm{Zn}$, and $\mathrm{Cu}$ were extracted from the soil samples with DTPA as described by [53] and measured by atomic absorption spectrophotometer.

2.4. Statistical Analysis. The soil physical and chemical properties were subjected to analysis of variance using the General Linear Model of two-way ANOVA by RCBD with factorial arrangement using SAS software version 9.0 [54]. The least significance difference (LSD 0.05) test was used to separate significantly differing treatment means.

\section{Results and Discussion}

\subsection{Soil Physical Properties}

3.1.1. Soil Texture. Both the SWCPs of soil bund (SB) and Fanya juu terrace (FT) resulted in significantly lower amounts of sand and higher amounts of silt and clay compared to the no conservation practice (NC) (Table 1). The mean values of sand under SB and FT were $34.8 \%$ and $39.8 \%$, respectively, compared to $55.5 \%$ under NC. The contents of silt were $32.3 \%$ and $27.7 \%$ for SB and FT, respectively, compared to $22.0 \%$ under NC. Likewise, the clay content was $32.8 \%$ and $32.5 \%$ under SB and FT, respectively, compared to $17.8 \%$ under NC. Accordingly, the soil textural class was clay loam for SB and FT and sandy loam for NC. There was, however, no significant difference in the distribution of textural separates among the two SWCPs of SB and FT. There was no significant variation $(P>0.05)$ between surface $(0-15 \mathrm{~cm})$ and subsurface $(15-30 \mathrm{~cm})$ soil depths (Table 1). Also, the interaction between SWCPs and soil depth was nonsignificant for soil textural separates.

The SWCPs of SB and FT may retard the process of soil erosion, thereby having more retention of silt and clay in the fields. Conversely, the land with no conservation practice may allow more movement of silt and clay along with runoff down the slope. That could be the reason for the fields to be coarse in texture under NC compared to SB- and FT-treated farm lands. The NC practice, therefore, showed deterioration in the soil resource by having more proportion of coarse sand fraction and less fine fractions of silt and clay. On the other hand, the soil under SB and FT having higher contents of fine fraction will have better water and nutrient retention and soil productivity. Similar results have been reported by other researchers [55-59] such that the sand fraction was significantly low while silt and clay contents were significantly higher in the conserved than the nonconserved farmland. For instance, significantly higher amount of clay content was found in treated fields, i.e., grassed bunds (33\%), soil bunds (28\%), and stone bunds (29\%), compared with the 

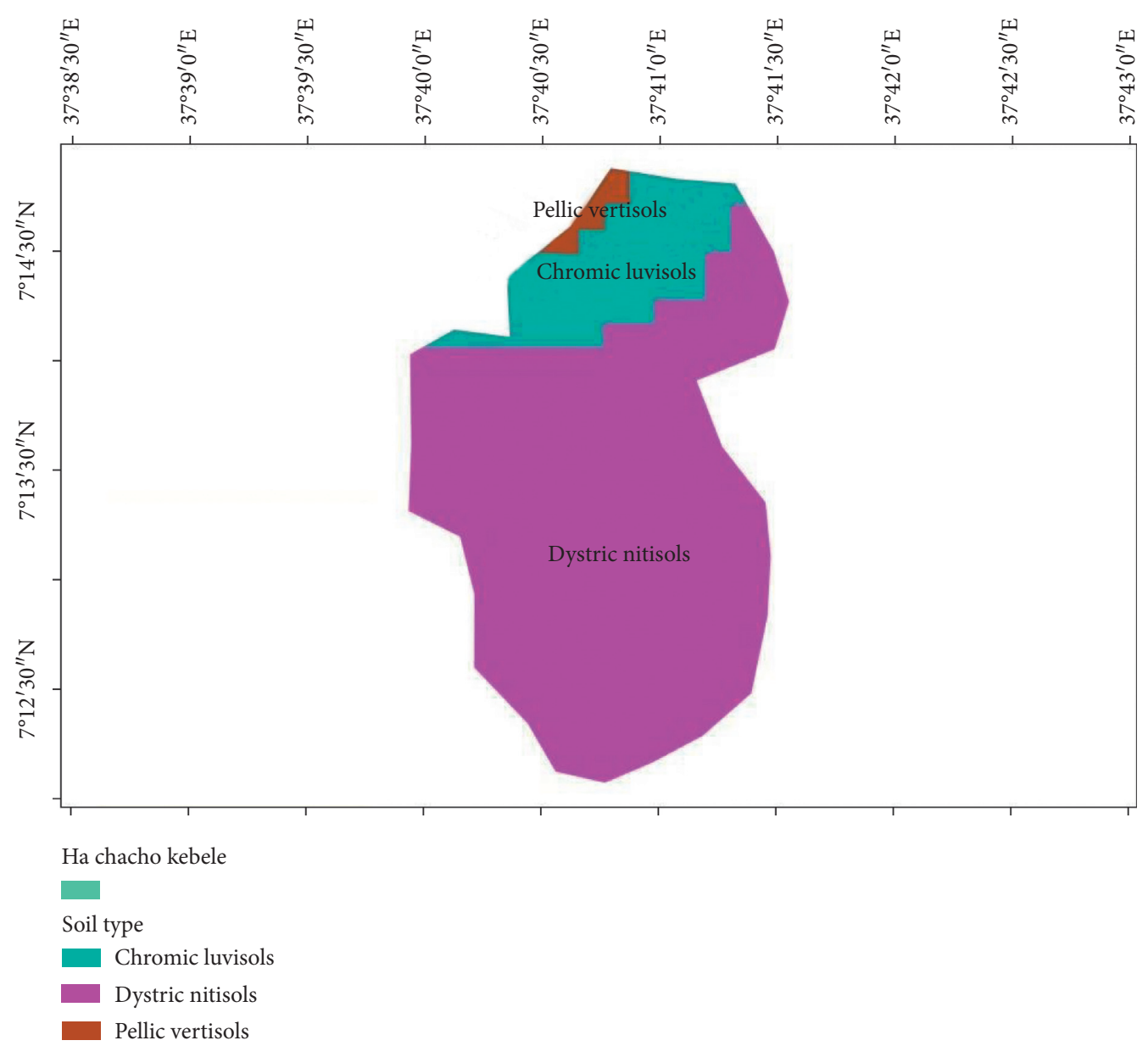

FIgURE 2: Soil map of Uwite watershed (extracted from soil map of Ethiopia, Agricultural Transformation Agency, 2012).

TABLE 1: Effect of soil conservation practices and soil depths on selected physical properties of soils in Uwite watershed.

\begin{tabular}{|c|c|c|c|c|c|c|c|}
\hline Treatment & Sand & $\begin{array}{l}\text { Silt } \\
(\%)\end{array}$ & Clay & STC & $\begin{array}{l}\mathrm{BD} \\
(\mathrm{mg} \\
\left.\mathrm{m}^{-3}\right)\end{array}$ & $\begin{array}{l}\mathrm{TP} \\
\quad(\%\end{array}$ & $\begin{array}{l}\text { SMC } \\
\text { 6) }\end{array}$ \\
\hline \multicolumn{8}{|c|}{ Soil conservation practice } \\
\hline SB & $34.83^{\mathrm{b}}$ & $32.33^{\mathrm{a}}$ & $32.83^{\mathrm{a}}$ & CL & $1.25^{\mathrm{b}}$ & $51.76^{\mathrm{a}}$ & $15.33^{\mathrm{a}}$ \\
\hline FT & $39.83^{\mathrm{b}}$ & $27.66^{\mathrm{a}}$ & $32.50^{\mathrm{a}}$ & $\mathrm{CL}$ & $1.29^{\mathrm{b}}$ & $50.74^{\mathrm{ab}}$ & $10.21^{\mathrm{b}}$ \\
\hline $\mathrm{NC}$ & $55.50^{\mathrm{a}}$ & $22.00^{\mathrm{b}}$ & $17.83^{\mathrm{b}}$ & SL & $1.37^{\mathrm{a}}$ & $48.54^{\mathrm{b}}$ & $7.01^{\mathrm{c}}$ \\
\hline $\operatorname{LSD}_{(0.05)}$ & 7.7 & 4.87 & 4.38 & & 0.077 & & 1.93 \\
\hline $\operatorname{SEM}( \pm)$ & 2.47 & 1.54 & 1.4 & & 0.024 & & 0.61 \\
\hline \multicolumn{8}{|c|}{ Soil depth $(\mathrm{cm})$} \\
\hline $0-15$ & $43.44^{\mathrm{a}}$ & $27.55^{\mathrm{a}}$ & $28.11^{\mathrm{a}}$ & CL & $1.27^{\mathrm{b}}$ & $51.30^{\mathrm{a}}$ & $11.46^{\mathrm{a}}$ \\
\hline $15-30$ & $43.33^{\mathrm{a}}$ & $27.11^{\mathrm{a}}$ & $27.33^{\mathrm{a}}$ & $\mathrm{CL}$ & $1.34^{\mathrm{a}}$ & $49.40^{\mathrm{b}}$ & $10.24^{\mathrm{a}}$ \\
\hline $\mathrm{LSD}_{(0 .}$ & & 3.98 & 3.57 & & 0.062 & 1.91 & 1.58 \\
\hline SEM ( & 2.4 & 1.26 & 1.13 & & 0.019 & 0.60 & 0.51 \\
\hline $\mathrm{CP}$ & $* *$ & $* *$ & $* *$ & & $* *$ & $*$ & $* *$ \\
\hline SD & & NS & & & $* *$ & $*$ & NS \\
\hline CV (\%) & 13.9 & 13.8 & 12.27 & & 4.56 & 3.6 & 13.8 \\
\hline
\end{tabular}

Figures followed by the same letter within a column for a given variable and parameter are not significantly different from each other at $P \leq 0.05$. $\mathrm{LSD}=$ least significant difference; $\mathrm{SEM}=$ standard error of the mean; $\mathrm{CV}=$ coefficient of variation; $\mathrm{SB}=$ soil bund; $\mathrm{FT}=$ Fanya Juu terrace; $\mathrm{NC}=$ nonconserved $\quad \mathrm{SMC}=$ soil moisture content; $\mathrm{TP}=$ total porosity; $\mathrm{CP}=$ conservation practices; and $\mathrm{SD}=$ soil depth. ${ }^{*}$ and ${ }^{* *}$ mean significant differences at 0.05 and 0.01 probability levels, respectively, and NS = means nonsignificant differences. untreated fields (24\%) in Simada district, northwest Ethiopia [56]. Also, the overall mean percentages of clay and silt contents were significantly higher in the treated fields with soil bund and stone-faced soil bund than the untreated fields, while the sand fraction was significantly lower in the treated than the untreated fields [59]. Further, [43] indicated significantly higher clay fractions under SWCPs such as soil bunds and Fanya juu compared to no conservation practice in Geshy subcatchment, Gojeb river catchment, Ethiopia.

3.1.2. Soil Bulk Density. The analysis of variance revealed that there was significant difference $(P<0.01)$ in bulk density (BD) between the conserved and unconserved cultivated lands (Table 1). The decreases in soil BD for the conservation practices of SB and FT were to the magnitude of about $9 \%$ and $6 \%$, respectively, compared to the NC. There was, however, no significant difference $(P>0.05)$ between the conservation practices of SB and FT. The result was in agreement with the findings of [44], who found bulk density of soil to be significantly lower under soil conservation practice of SB $\left(1.08 \mathrm{mg} \cdot \mathrm{m}^{-3}\right)$ compared to practice of no conservation $\left(1.17 \mathrm{mg} \cdot \mathrm{m}^{-3}\right)$ in Mawula watershed, southern Ethiopia. Similar results were also revealed by [42, 58-61] for south Gonder, southern Ethiopia, Ginaberet, Adaa Berga district in western Ethiopia and Lole watershed 
in the northwest highlands of Ethiopia, respectively. The lower soil BD under SWCPs may be due to more amounts of clay and soil organic matter, conditioned by reduced soil erosion. Testifying the same, the $\mathrm{BD}$ showed significant negative correlation of $-0.73^{* *}$ with clay and $-0.68^{* *}$ with soil organic matter (Table 2). The low BD under SWCPs may favour plant growth by having better soil-water functions and less mechanical impedance to root growth. The BD of the surface layer $\left(1.27 \mathrm{mg} \mathrm{m}^{-3}\right)$ was found to be significantly lower than that of the subsurface layer $\left(1.34 \mathrm{mg} \mathrm{m}^{-3}\right)(\mathrm{Ta}-$ ble 1). This may indicate more amount of organic matter input from crop residue on topsoil than subsoil layer. Soils with high organic matter content are likely to have low mass and more pore space that, in turn, reduces BD of the soils. The interaction between SWCPs and soil depth was, however, nonsignificant $(P>0.05)$ for $\mathrm{BD}$.

3.1.3. Total Porosity. The total porosity (TP) was significantly $(P<0.05)$ affected by SWCPs (Table 1$)$. The practice of SB had a significantly higher value of porosity $(51.76 \%)$ than $\mathrm{NC}$ (48.54\%), while FT was statistically similar to NC (Table 1 ). The highest TP observed for the conserved farmland with SB might be due to more retention of clay and silt fractions and organic matter, favoring better structural development and mass-volume relationship. The role of organic matter on total porosity has been shown by $[39,62]$. The improved soil aggregation can create more macro- and micropores capable of enhancing water retention and transmission characteristics of soil. A significant increase in percent porosity under soil bund $(65.97 \pm 4.61)$ and stone-faced soil bund $(64.63 \pm 3.57)$ than control $(59.83 \pm 2.43)$ has also been reported by [59] for Lole watershed, northwest highlands of Ethiopia. The study is also in agreement with finding of [57] who reported a higher mean value of soil porosity in conserved farm land compared to nonconserved fields. This implied that an increase in soil organic matter content, as a result of high surface residue cover due to soil conservation practice, increased the total porosity of soils.

The TP was also significantly $(P<0.05)$ affected by soil depth (Table 1). The mean value of TP at the surface $(0-15 \mathrm{~cm})$ soil was significantly higher than the subsurface soil layer $(15-30 \mathrm{~cm})$ (Table 1$)$. The lower value of porosity in subsurface layer could be due to less accumulation of organic matter and higher bulk density.

3.1.4. Soil Moisture Content. The soil moisture content (SMC) was significantly influenced by soil conservation practices (Table 1). Both SB and FT had significantly higher SMC compared to NC, showing increases of about 119 and 46 percent, respectively, over NC (Table 1). Further, the value of SMC under SB was significantly higher than FT practice. Similar increases of volumetric water content have been shown with SWCPs of soil bund and Fanya juu in Geshy subcatchment, Gojeb river catchment, Ethiopia [43]. Also, [44] have reported significantly higher soil moisture content under SB (22.5\%) compared to no conservation practice (12.2\%) for cultivated lands in Mawula Watershed, Loma District, southern Ethiopia. It was indicated by [63] that soil bunds are used to prevent runoff and provide more opportunity for water to infilter into the soil profile. Also, higher amounts of clay and organic matter in SWCPs would help retain more water by the soils, as revealed by significant positive correlations of SMC with clay $\left(r=0.68^{* *}\right)$ and organic matter $\left(r=0.73^{* *}\right)$. The stored water in soil profile could be used more efficiently by the crops later in the season.

The soil moisture was not significantly affected either by soil depth (Table 1) or by the interaction between soil conservation practice and soil depth.

\subsection{Soil Chemical Properties}

3.2.1. Soil Reaction. The soil reaction $(\mathrm{pH})$ was significantly $(P<0.01)$ affected by soil conservation practices (Table 3$)$. It increased for the farmlands treated with SB and FT by $13.14 \%$ and $9.85 \%$, respectively, compared with the NC (control) (Table 3). Similarly, [39] had reported that soil pH significantly varied within conservation practices and it was lower in nonconserved farmland and higher in the Fanya juu terraced farmland in Goromti watershed, western Ethiopia. A significant improvement in soil $\mathrm{pH}$ under SWCPs of soil bund and Fanya juu has also been indicated by [43] for Geshy subcatchment of Gojeb river catchment, Ethiopia. Further, a significant increase in $\mathrm{pH}$ was noticed for the farmlands treated with soil bund $(6.51 \pm 0.32)$ and stonefaced soil bund $(6.48 \pm 0.26)$ compared to the unconserved farmland $(5.90 \pm 0.48)$ in Lole watershed, northwest highlands of Ethiopia [59]. The removal of topsoil due to erosion under no conservation practice exposes the subsoil to the surface resulting in lower $\mathrm{pH}$ [55]. The higher value of $\mathrm{pH}$ in the conserved farm land could be credited to the presence of more content of clay and organic matter that help retain more basic cations in soil due to their adsorption on colloidal surfaces. The soil $\mathrm{pH}$ was significantly $(P<0.05)$ lower in $15-30 \mathrm{~cm}$ soil layer (5.83) compared to $0-15 \mathrm{~cm}$ soil layer (5.98) (Table 3). Similar trend was shown by [64] that the $\mathrm{pH}$ was slightly decreased with increasing soil depth. The reason for such an occurrence could be the decrease of clay and organic matter contents with depth that retained basic cations to raise soil $\mathrm{pH}$.

According to the rating of [65], the $\mathrm{pH}$ under SB and FT was slightly acidic, while it was moderately acidic under NC practice. The near neutrality soil pH under SWCPs would favour mineralization of SOM and release of nutrients in soil besides preventing fixation of nutrients like $\mathrm{P}, \mathrm{Ca}$, and $\mathrm{Mo}$ in acidic soil range.

The reason for such a phenomenon could be the decrease of SOM and basic cations such as $\mathrm{Ca} 2+, \mathrm{K}+$, and $\mathrm{Mg} 2+$ along soil depth which decreases soil $\mathrm{pH}$ from top to down the soil layers, showing strong positive and significant correlation with SOM $\left(r=0.92^{* *}\right)$, TN $\left(r=0.88^{* *}\right)$, Av.P $\left(r=0.90^{* *}\right)$, CEC $\left(r=0.87^{* *}\right), \mathrm{Ca} 2+\left(=0.89^{* *}\right)$, and exchangeable $\mathrm{K}+$ $\left(r=0.85^{* *}\right)$ (Table 2).

3.2.2. Soil Organic Matter. Soil organic matter (SOM) content was significantly $(P<0.05)$ affected by interaction between SWCPs and soil depths (Table 4). A significant 


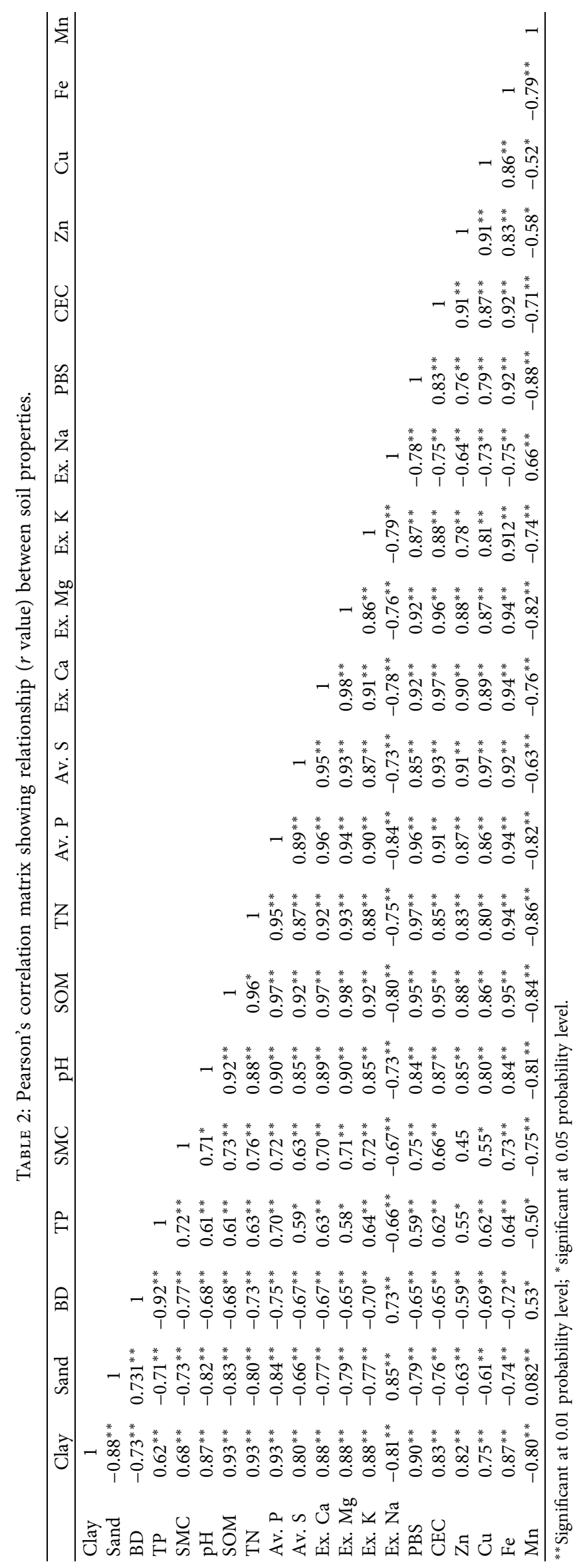


TABLE 3: Effect of soil conservation practices and soil depths on selected chemical properties of soils in Uwite watershed.

\begin{tabular}{|c|c|c|c|c|c|c|c|c|}
\hline Treatment & $\mathrm{pH}$ & TN (\%) & Av. P & Av. S & Ex. K & $\begin{array}{c}\text { Ex. Na } \\
\text { cmol (+) } \mathrm{kg}^{-1}\end{array}$ & CEC & PBS \\
\hline \multicolumn{9}{|c|}{ Soil conservation practice } \\
\hline SB & $6.20^{\mathrm{a}}$ & $0.21^{\mathrm{a}}$ & $9.07^{\mathrm{a}}$ & $1.82^{\mathrm{a}}$ & $0.83^{\mathrm{a}}$ & $0.12^{\mathrm{b}}$ & $26.36^{\mathrm{a}}$ & $58.78^{\mathrm{a}}$ \\
\hline FT & $6.02^{\mathrm{a}}$ & $0.20^{\mathrm{a}}$ & $9.33^{\mathrm{a}}$ & $1.90^{\mathrm{a}}$ & $0.85^{\mathrm{a}}$ & $0.12^{\mathrm{b}}$ & $27.03^{\mathrm{a}}$ & $58.3^{\mathrm{a}}$ \\
\hline NC & $5.48^{\mathrm{b}}$ & $0.11^{\mathrm{b}}$ & $3.40^{\mathrm{b}}$ & $1.21^{\mathrm{b}}$ & $0.23^{\mathrm{b}}$ & $0.17^{\mathrm{a}}$ & $10.5^{\mathrm{b}}$ & $25.36^{\mathrm{b}}$ \\
\hline $\operatorname{LSD}_{(0.05)}$ & 0.17 & 0.02 & 0.87 & 0.12 & 0.18 & 0.03 & 2.69 & 5.83 \\
\hline $\operatorname{SEM}( \pm)$ & 0.05 & 0.01 & 0.38 & 0.04 & 0.057 & 0.0087 & 0.95 & 1.85 \\
\hline \multicolumn{9}{|c|}{ Soil depth $(\mathrm{cm})$} \\
\hline $0-15$ & $5.98^{\mathrm{a}}$ & $0.18^{\mathrm{a}}$ & $7.83^{\mathrm{a}}$ & $1.81^{\mathrm{a}}$ & $0.68^{\mathrm{a}}$ & $0.13^{\mathrm{a}}$ & $24.55^{\mathrm{a}}$ & $47.67^{\mathrm{a}}$ \\
\hline $15-30$ & $5.83^{\mathrm{b}}$ & $0.17^{\mathrm{a}}$ & $6.70^{\mathrm{b}}$ & $1.49^{\mathrm{b}}$ & $0.58^{\mathrm{a}}$ & $0.15^{\mathrm{a}}$ & $18.05^{\mathrm{b}}$ & $47.29^{\mathrm{a}}$ \\
\hline $\operatorname{LSD}_{(0.05)}$ & 0.14 & 0.015 & 0.71 & 0.10 & 0.15 & 0.02 & 2.25 & 4.76 \\
\hline $\operatorname{SEM}( \pm)$ & 0.045 & 0.047 & 0.22 & 0.03 & 0.05 & 0.01 & 0.77 & 1.51 \\
\hline $\mathrm{CP}$ & ** & $* *$ & $* *$ & $* *$ & $* *$ & $* *$ & $* *$ & $* *$ \\
\hline $\mathrm{SD}$ & $*$ & NS & $* *$ & $* *$ & NS & NS & $* *$ & NS \\
\hline CV (\%) & 2.3 & 8.24 & 8.9 & 5.85 & 22.0 & 15.29 & 10.93 & 9.55 \\
\hline
\end{tabular}

Figures followed by the same letter with in a column are not significantly different from each other at $P \leq 0.05$. LSD $=$ least significant difference; $\mathrm{SEM}=$ standard error of the mean; $\mathrm{CV}=$ coefficient of variation; $\mathrm{SB}=$ soil bund; $\mathrm{FT}=$ Fanya juu terrace; $\mathrm{NC}=$ nonconserved farm land; $\mathrm{CP}=$ conservation practices; and $\mathrm{SD}=$ soil depth. ${ }^{*}$ and ${ }^{* *}$ mean significant differences at 0.05 and 0.01 probability levels, respectively, and NS $=$ nonsignificant.

TABLE 4: Effect of soil conservation practices and soil depths on chemical properties of soils in the Uwite watershed.

\begin{tabular}{|c|c|c|c|c|}
\hline \multirow[b]{2}{*}{ Soil conservation practice } & \multicolumn{2}{|c|}{ Depth } & \multirow[b]{2}{*}{$\begin{array}{l}\text { Ex. Ca } \\
\qquad \mathrm{cmol}(+\end{array}$} & \multirow[b]{2}{*}{$\begin{array}{l}\text { Ex. } \mathrm{Mg} \\
\mathrm{kg}^{-1}\end{array}$} \\
\hline & $\mathrm{cm}$ & $\begin{array}{c}\text { SOM } \\
(\%)\end{array}$ & & \\
\hline \multirow{2}{*}{ SB } & $0-15$ & $4.07^{\mathrm{a}}$ & $13.40^{\mathrm{a}}$ & $3.40^{\mathrm{a}}$ \\
\hline & $15-30$ & $3.56^{\mathrm{b}}$ & $9.66^{\mathrm{b}}$ & $2.35^{\mathrm{b}}$ \\
\hline \multirow{2}{*}{ FT } & $0-15$ & $3.95^{\mathrm{a}}$ & $14.16^{\mathrm{a}}$ & $3.10^{\mathrm{a}}$ \\
\hline & $15-30$ & $3.62^{\mathrm{b}}$ & $9.76^{\mathrm{b}}$ & $2.56^{\mathrm{b}}$ \\
\hline \multirow{2}{*}{ NC } & $0-15$ & $2.01^{\mathrm{c}}$ & $3.23^{\mathrm{c}}$ & $0.52^{\mathrm{c}}$ \\
\hline & $15-30$ & $1.89^{\mathrm{c}}$ & $2.30^{\mathrm{dc}}$ & $0.33^{\mathrm{c}}$ \\
\hline LSD $(0.05)$ & & 0.17 & 0.98 & 0.35 \\
\hline SEM $( \pm)$ & & 0.05 & 0.31 & 0.11 \\
\hline$P$ value & & $*$ & $* *$ & $* *$ \\
\hline CV (\%) & & 3.01 & 6.40 & 9.45 \\
\hline
\end{tabular}

Figures followed by same letter(s) within a column are not significantly different from each other at $P \leq 0.05$. LSD = least significant difference; $\mathrm{SEM}=$ standard error of means; $\mathrm{CV}=$ coefficient of variation; $\mathrm{SB}=$ soil bund; FT = Fanya Juu terrace; and $\mathrm{NC}=$ non-conserved land. ${ }^{*}$ and ${ }^{* *}$ mean significant differences at 0.05 and 0.01 probability levels, respectively.

increase in SOM was recorded under SB and FT both for surface $(0-15 \mathrm{~cm})$ and subsurface $(15-30 \mathrm{~cm})$ layers compared to NC (Table 4). The SOM contents were statistically similar for SB and FT. A number of studies $[39,44,58,60,64]$ have indicated the increases in SOM under different SWCPs compared to nonconserved farmlands. For instance, [39] found soil organic carbon (SOC) content to be significantly higher under Fanya juu structure maintained for 5 years $(2.21 \%)$ and 10 years $(2.17 \%)$ compared to control condition (1.96\%) in Goromti watershed, western Ethiopia. Likewise, the SOC was significantly higher under soil bund $(2.08 \%)$ compared to no management $(0.51 \%)$ in Mawula watershed, southern Ethiopia [44]. Further, in a recent study [43], the farmlands treated with SWCPs (soil bund and Fanya juu) had significantly improved SOC $(3.21 \%)$ than the farmlands without SWCPs
(3.03). In another recent study [59], the percent SOC in farmlands treated with soil bund $(1.76 \pm 0.47)$ and stonefaced soil bund $(2.20 \pm 0.65)$ was significantly higher than untreated farmlands $(1.44 \pm 0.45)$.

The presence of SWCPs would reduce surface runoff and soil loss, retain more water and nutrients, enhance crop growth, and contribute to soil organic matter build-up in soils. If maintained properly for long, the practices like SB and FT would, eventually, develop to bench terrace, having marked influence on reduction of soil erosion and enhancement of SOM and soil productivity. The required SOM level in soil governs favorably all physical and chemical soil quality indicators [43] influencing soil-water functions and nutrient availability. The SOM has been rated as a key attribute of soils to illustrate its importance for soil functions and ecosystem services and overall realization of Sustainable Development Goals of the UN [4].

Based on rating of [65], the SOM content under SWCPs of SB and FT was medium, while it was low under NC. Therefore, the farmlands without adequate protection through SWCPs would suffer SOM depletion and consequent decline in soil and crop productivity.

3.2.3. Nutrient Contents. The total nitrogen (TN), available phosphorus (Av. P), and available sulphur (Av. S) contents of the soils were significantly $(P<0.01)$ affected by SWCPs (Table 3) and both the practices of SB and FT were having significantly higher contents of TN, Av. P, and Av. S compared to NC practice. The increases under SB and FT compared to NC were 91 and $82 \%$ for TN, 167 and $174 \%$ for Av. P, and 50 and 57\%, for Av. S, respectively (Table 3). Similar increases in nutrients under SWCPs compared to no conservation practice have been indicated in some recent studies. For instance, [59] found a significant increase in \% TN under soil bund $(0.31 \pm 0.09)$ and stone-faced soil bund $(0.35 \pm 0.07)$ compared to control $(0.19 \pm 0.06)$ in Lole 
watershed, northwest highlands of Ethiopia. In the same study, the Av. $\mathrm{P}\left(\mathrm{mg} \mathrm{kg}^{-1}\right)$ also increased significantly under soil bund (12.4 \pm 5.76$)$ and stone-faced soil bund $(12.95 \pm 5.27)$ compared to control $(7.94 \pm 2.63)$. Likewise, [44] found significant increases under practices of SB and SB + FYM compared to no management by 67 and 133\% for TN and 77 and $182 \%$ for Av. P, respectively, in Mawula watershed, southern Ethiopia. The increases with SWCPs in TN and Av. P, although nonsignificant, have also been indicated by [43] in Geshy subcatchment, Gojeb River catchment, Ethiopia. A significant increase in $\mathrm{N}$ content from $0.17 \%$ in control to $0.24 \%$ under Fanya juu-treated farmland for 10 years has also been reported by [39] for Goromti watershed, western Ethiopia. Some earlier studies bib61[56, 60, 64] have also shown the increased nutrient contents with SWCPs compared to no conservation practice on farmlands.

The increased nutrient availability under SWCPs could be related to higher amounts of SOM in them. A bulk of nutrient elements like $\mathrm{N}, \mathrm{P}$, and $\mathrm{S}$ occurs in soil as part of organic molecules, which gets mineralized to become slowly available to plants. The SOM having large bearing on the availability of nutrients in soils was reflected in having highly significant positive correlations between $\mathrm{SOM}$ and TN $\left(0.96^{* *}\right)$, Av. P $\left(0.97^{* *}\right)$, and Av. S $\left(0.92^{* *}\right)$ (Table 2).

The soil depth had no significant effect on TN content, but it was significant for Av. P and Av. S (Table 3). The Av. P decreased from $7.83 \mathrm{mg} \mathrm{kg}^{-1}$ in surface layer to $6.70 \mathrm{mg} \mathrm{kg}^{-1}$ in subsurface layer. The Av. $S$ decreased from $1.81 \mathrm{mg} \mathrm{kg}^{-1}$ in surface layer to $1.49 \mathrm{mg} \mathrm{kg}^{-1}$ in subsurface layer. A significant difference for Av. $\mathrm{P}$ in top and subsoil layers has also been found by [66] in a study on Anjeni watershed, central highlands of Ethiopia. The difference in nutrient level in surface and subsurface layers could be explained to SOM levels which decreased with soil depth.

According to the rating given by [65] for $\mathrm{N}$ and by [51] for $\mathrm{P}$, the $\mathrm{N}$ and $\mathrm{P}$ contents under $\mathrm{SB}$ and FT were moderate/ medium and low under NC. The Av. S, although, higher under SB and FT, was at critical level for all the practices. This was obvious as soils belonging to Nitisols in Rift valley, Ethiopia, are reported to be having lowest soluble sulfate content, which is below the critical level for crop production [67].

3.2.4. Exchangeable Cations and Cation Exchange Capacity. The interaction between conservation practices and soil depth showed significant $(P<0.01)$ variation for exchangeable $\mathrm{Ca}$ and $\mathrm{Mg}$, which decreased significantly with soil depth except for NC (Table 4). The SWCPs of SB and FT showed significantly higher values of exchangeable $\mathrm{Ca}$ and $\mathrm{Mg}$ both for surface and subsurface soil depths compared to NC practice. The exchangeable $\mathrm{K}$ was also significantly higher under SB and FT (Table 3). The overall trend of availability of basic cations under SWCPs was $\mathrm{SB}=\mathrm{FT}>\mathrm{NC}$. The cation exchange capacity (CEC) was also significantly higher under SB $\left(26.36 \mathrm{cmol} \mathrm{kg}^{-1}\right)$ and FT $\left(27.03 \mathrm{cmol} \mathrm{kg}^{-1}\right)$ compared to NC $\left(10.5 \mathrm{cmol} \mathrm{kg}^{-1}\right)$ (Table 3$)$. The higher contents of exchangeable basic cations and CEC under
SWCPs of SB and SB + FYM have been reported by [44] for Mawula watershed, southern Ethiopia. Similarly, significantly higher values of CEC are reported for soil bund $\left(30.06 \pm 10.00 \mathrm{cmol} \mathrm{kg}{ }^{-1}\right)$ and stone-faced soil bund $\left(36.51 \pm 4.98 \mathrm{cmol} \mathrm{kg}^{-1}\right)$ compared to control condition $\left(22.86 \pm 5.28 \mathrm{cmol} \mathrm{kg}^{-1}\right)$ for Geshy subcatchment, Gojeb river catchment, Ethiopia [43]. The same study also recorded significantly higher contents of K under the SWCPs compared to control.

The higher values of basic cations and CEC under SWCPs could be credited to higher amounts of clay and organic matter in them. Conversely, the low contents of exchangeable cations and CEC under NC could be due to more erosion of clay and organic matter fractions that retain nutrient cations. The influence of clay and SOM on exchangeable cations and CEC is very well depicted in having highly significant positive correlations between them. The " $r$ " values for the relationship between clay and exchangeable $\mathrm{Ca}, \mathrm{Mg}, \mathrm{K}$, and CEC were $0.88^{* *}, 0.88^{* *}, 0.88^{* *}$, and $0.83^{* *}$, respectively (Table 2 ). Likewise, the " $r$ " values for the relationship between $\mathrm{SOM}$ and exchangeable $\mathrm{Ca}, \mathrm{Mg}, \mathrm{K}$, and CEC were $0.97^{* *}, 0.98^{* *}, 0.92^{* *}$, and $0.95^{* *}$, respectively.

As per ratings given by [68], the status of exchangeable $\mathrm{Ca}, \mathrm{Mg}$, and $\mathrm{K}$ was high, medium to high, and high, respectively, under SWCPs and low under no conservation practice. The CEC as per rating by [69] was high under SWCPs and low under no conservation practice. The higher CEC in soils under SWCPs will ensure greater and sustainable supplies of nutrients to growing crops.

3.2.5. Percent Base Saturation. The percent base saturation (PBS) is a measure of saturation of soil exchange complex with basic cations and is an important indicator of soil fertility status of soils. It was significantly higher under SB (58.78\%) and FT (58.3\%) compared to NC (25.36\% (Table 3). The PBS under NC far below $50 \%$ could be due to intensive soil erosion removing fine fraction of soil as well as SOM retaining bases on exchange complex, as also suggested by [70]. The influence of clay and SOM on PBS is evidenced by highly significant and positive relationship between them. The coefficient of correlation ( $r$ value) between clay and PBS and between SOM and PBS was $0.90^{* *}$ and $0.95^{* *}$, respectively (Table 2). As per rating by Hazelton and Murphy [69], the soils under SWCPs were moderate in PBS status and low under no conservation practice.

The PBS was not affected by soil depth as well as by the interaction of conservation practice and soil depth.

3.2.6. Micronutrients. The contents of micronutrients, viz., $\mathrm{Fe}^{2+}, \mathrm{Mn}^{2+}, \mathrm{Zn}^{2+}$, and $\mathrm{Cu}^{2+}$, were significantly affected by the soil conservation practices and soil depths. Both the SWCPs of SB and FT recorded significantly higher contents of micronutrients compared to NC; the increases over NC were $35-38 \%$ for $\mathrm{Fe}, 40-55 \%$ for $\mathrm{Zn}$, and $43-57 \%$ for $\mathrm{Cu}$ (Table 5).

Similar significant increases in micronutrient contents (Fe, Mn, $\mathrm{Zn}$, and $\mathrm{Cu}$ ) under SWCPs (SB and SB + FYM) compared to no management practice have been reported in 
TABLE 5: Effect of soil conservation practices and soil depths on micronutrient contents in soils of Uwite watershed.

\begin{tabular}{lcccc}
\hline Treatment & $\mathrm{Fe}$ & $\mathrm{Mn}$ & $\mathrm{Zn}$ & $\mathrm{Cu}$ \\
& \multicolumn{4}{c}{$\mathrm{mg} \mathrm{kg}^{-1}$} \\
\hline Soil conservation & practice & & & \\
SB & $4.20^{\mathrm{a}}$ & $1.58^{\mathrm{c}}$ & $0.56^{\mathrm{a}}$ & $0.20^{\mathrm{a}}$ \\
FT & $4.30^{\mathrm{a}}$ & $1.72^{\mathrm{b}}$ & $0.62^{\mathrm{a}}$ & $0.22^{\mathrm{a}}$ \\
NC & $3.11^{\mathrm{b}}$ & $2.22^{\mathrm{a}}$ & $0.40^{\mathrm{b}}$ & $0.14^{\mathrm{b}}$ \\
\hline LSD $(0.05)$ & 0.20 & 0.113 & 0.06 & 0.018 \\
SEM $( \pm)$ & 0.058 & 0.036 & 0.018 & 0.006 \\
\hline Soil depth $(\mathrm{cm})$ & & & & \\
0-15 & $4.00^{\mathrm{a}}$ & $1.90^{\mathrm{a}}$ & $0.58^{\mathrm{a}}$ & $0.21^{\mathrm{a}}$ \\
15-30 & $3.7^{\mathrm{b}}$ & $1.77^{\mathrm{b}}$ & $0.48^{\mathrm{b}}$ & $0.16^{\mathrm{b}}$ \\
\hline LSD $(0.05)$ & 0.15 & 0.09 & 0.046 & 0.015 \\
SEM $( \pm)$ & 0.05 & 0.03 & 0.05 & 0.005 \\
CP & $* *$ & $* *$ & $*^{* *}$ & $* *$ \\
SD & $* *$ & $* *$ & $* *$ & $* *$ \\
CV $(\%)$ & 3.67 & 4.86 & 8.3 & 7.5 \\
\hline
\end{tabular}

Figures followed by the same letter(s) within a column for a given variable are not significantly different from each other at $P \leq 0.05$. SB $=$ soil bund, $\mathrm{FT}=$ Fanya juu terrace, and $\mathrm{NC}=$ non-conserved farmland. $\mathrm{LSD}=$ least significant difference; $\mathrm{SEM}=$ standard error of means; $\mathrm{CV}=$ coefficient of variation; $\mathrm{CP}=$ conservation practices; and $\mathrm{SD}=$ soil depth. ${ }^{*}$ and ${ }^{* *}$ mean significant differences at 0.05 and 0.01 probability levels, respectively.

a recent study [44] in Mawula watershed, southern Ethiopia. The increased solubility and availability of micronutrient cations under conservation practices were probably due to increases in the SOM amounts in them, as evidenced by significant and positive correlations of SOM with $\mathrm{Fe}$ $\left(r=0.95^{* *}\right), \mathrm{Zn}\left(r=0.88^{* *}\right)$, and $\mathrm{Cu}\left(r=0.86^{* *}\right)$ (Table 2).

The organic matter decomposition products act as chelating agents with micronutrient cations as central atom, preventing their precipitation and increasing availability in soils. The $0-15 \mathrm{~cm}$ soil depth indicated significantly higher micronutrient contents than $15-30 \mathrm{~cm}$ soil depth. The effect was, obviously, due to higher SOM levels in surface layer.

The widespread land degradation in the study area has brought significant reductions in the SOM levels and availability of micronutrients. The emergence of micronutrient deficiencies in the Hadero Tunto Zuria woreda is confirmed by the soil fertility and fertilizer map prepared for the area by ATA [25]. Therefore, under no soil conservation practice, the soils need to be replenished with deficient micronutrients besides the primary nutrients like NPK. The Ministry of Agriculture, Ethiopia, has already taken the initiative of popularizing blended fertilizers with micronutrients specific to different areas. However, such a contingency may not arise, should the lands be provided with appropriate SWCPs maintaining adequate levels of SOM and micronutrients in soils.

From the foregoing, it was evident that farmlands without any protection were impoverished and required appropriate SWCPs for the maintenance of soil fertility and crop productivity. In a recent study [59], the crop yields have been shown to be increased under SWCPs maintaining higher soil fertility.

\section{Conclusion}

The soil and water conservation practices of soil bund and Fanya juu terrace implemented for the last ten years on Uwite watershed in Ha-Chacho kebele, Hadero Tunto district revealed positive effect on various soil physical and chemical properties of soil. Both the practices, at par with each other, indicated significantly higher content of clay, lower bulk density, higher total porosity, higher moisture content, higher $\mathrm{pH}$, higher soil organic matter, higher percent base saturation, higher cation exchange capacity, higher amounts of macro- $(\mathrm{N}, \mathrm{P}, \mathrm{K}, \mathrm{Ca}, \mathrm{Mg}$, and $\mathrm{S})$ and micronutrients $(\mathrm{Fe}, \mathrm{Zn}$, and $\mathrm{Cu}$ ) compared to no conservation practice. The surface soil layer $(0-15 \mathrm{~cm})$ was significantly superior to the subsurface layer $(15-30 \mathrm{~cm})$ in terms of most of these soil properties. Therefore, both the existing practices merit their continuation and upscaling to new degraded areas in the watershed to ensure sustainable land productivity and quality of environment. The findings may be validated further by ascertaining crop yield and socioeconomic variables related to soil and water conservation practices. Also, the awareness on the potential benefits of conservation practices in realizing the Sustainable Development Goals of United Nations (more relevant for African continent) should be created among various stakeholders, including government organizations, development agents, NGOs, and farming community.

\section{Data Availability}

All the data related to the research will be made available upon a specific request.

\section{Conflicts of Interest}

The authors declare that they have no conflicts of interest regarding the publication of this paper.

\section{Acknowledgments}

The authors gratefully acknowledge the research grant from the Hadero Tunto Zuria Woreda Agriculture and Natural Resources Office in collaboration with Arba Minch University, Ethiopia.

\section{References}

[1] H. Hurni, A. Solomon, B. Amare et al., "Land degradation and sustainable land management in the highlands of Ethiopia," in Global Change and Sustainable Development: A Synthesis of Regional Experiences from Research Partnerships, H. Hurni and U. Wiesmann, Eds., vol. 5, pp. 187-201, Geographica Bernensia, Bern, Switzerland, 2010.

[2] D. T. Meshesha, A. Tsunekawa, and M. Tsubo, "Continuing land degradation: cause-effect in Ethiopia's central Rift valley," Land Degradation \& Development, vol. 23, no. 2, pp. 130-143, 2012.

[3] T. Gashaw, A. Bantider, and H. Silassie, "Land degradation in Ethiopia: causes, impacts and rehabilitation techniques," 
Journal of Environment and Earth Science, vol. 4, no. 9, pp. 98-104, 2014.

[4] S. D. Keesstra, J. Bouma, J. Wallinga et al., "The significance of soils and soil science towards realization of the United Nations sustainable development goals," Soil, vol. 2, no. 2, pp. 111-128, 2016.

[5] R. Scholes, R. Montanarella, L. Brainich et al., Summary for Policymakers of the Thematic Assessment Report on Land Degradation and Restoration of the Intergovernmental SciencePolicy Platform on Biodiversity and Ecosystem Services, pp. 1-31, IPBES Secretariat, Bonn, Germany, 2018.

[6] A. Hamdy and A. Aly, "Land degradation, agriculture productivity and food security," in Proceedings of the Fifth International Scientific Agricultural Symposium, Agrosym, pp. 708-717, Sarajevo, Bosnia, October 2014.

[7] O. K. Kirui and A. Mirzabaev, "Economics of land degradation in Eastern Africa," in Proceedings of the Tropentang 2014, Prague, Czeck Republic, September 2014.

[8] O. K. Kirui, "Impact of land degradation on household poverty: evidence from a panel data simultaneous equation model," in Proceedings of the 5th International Conference of the African Association of Agricultural Economists, Addis Ababa, Ethiopia, September 2016.

[9] E. B. Barbier, "The economic linkages between rural poverty and land degradation: some evidence from Africa," Agriculture, Ecosystems \& Environment, vol. 82, no. 1-3, pp. 355-370, 2000.

[10] S. Keesstra, G. Mol, J. de Leeuw et al., "Soil-related sustainable development goals: four concepts to make land degradation neutrality and restoration work," Land, vol. 7, p. 133, 2018.

[11] D. Griggs, M. Stafford-Smith, M. Gaffney et al., "Sustainable development goals for people and planet," Nature, vol. 495, pp. 305-307, 2013.

[12] T. Girma, Land Degradation: A Challenge to Ethiopia, International Livestock Research Institute, Addis Ababa, Ethiopia, 2001.

[13] MoARD (Ministry of Agriculture and Rural Development), Ethiopia's Agricultural Sector Policy and Investment Framework (PIF) 2010-2020, Draft Final Report, MoARD (Ministry of Agriculture and Rural Development), Hanoi, Vietnam, 2010.

[14] J. Nyssen, J. Poesen, J. Moeyersons, J. Deckers, M. Haile, and A. Lang, "Human impact on the environment in the Ethiopian and Eritrean highlands a state of the art," Earth-Science Reviews, vol. 64, pp. 273-320, 2004.

[15] M. Mekonnen and A. M. Melesse, "Soil erosion mapping and hotspot area identification using GIS and remote sensing in northwest Ethiopian highlands, near lake Tana," in Nile River Basin Hydrology Climate \& Water Use, A. M. Melesse, Ed., pp. 207-224, Springer, Berlin, Germany, 2011.

[16] E. Assefa and H. R. Bork, "Farmers' perception of land degradation and traditional knowledge in Southern Ethiopiaresilience \& stability," Land Degradation and Development, vol. 27, pp. 1552-1561, 2015.

[17] W. Kidane, "Identification and prioritization of sub watersheds for land and water management in Tekeze dam watershed, Northern Ethiopia," International Soil and Water Conservation Research, vol. 4, pp. 30-38, 2016.

[18] M. Mekonnen, S. D. Keesstra, J. E. M. Baartman, L. Stroosnijder, and J. Maroulis, "Reducing sediment connectivity through man-made and natural sediment sinks in the Minizr catchment, Northwest Ethiopia," Land Degradation and Development, vol. 28, pp. 708-717, 2016.
[19] W. Bewket and E. Teferi, "Assessment of soil erosion hazard and prioritization for treatment at the watershed level: case study in the Chemoga watershed, Blue Nile basin, Ethiopia," Land Degradation \& Development, vol. 20, no. 6, pp. 609-622, 2009.

[20] K. Hurni, G. Zeleke, M. Kassie et al., "Economics of land degradation Ethiopia. soil degradation and sustainable land management in the rainfed agricultural areas of Ethiopia: an assessment of the economic implications," Report for the Economics of Land Degradation Initiative, vol. 94, 2015.

[21] H. S. Gelagay and A. S. Minale, "Soil loss estimation using GIS and remote sensing techniques: a case of Koga watershed, Northwestern Ethiopia," International Soil and Water Conservation Research, vol. 4, no. 2, pp. 126-136, 2016.

[22] G. Temeshgen, T. Taffa, and A. Mekuria, "Erosion risk assessment for prioritization of conservation measures in Geleda watershed, Blue Nile Basin, Ethiopia," Environmental Systems Research, vol. 6, no. 1, 2017.

[23] H. F. Murphy, "Fertility and other data on some Ethiopian soils," in Proceedings of the Soil Fertility Management Workshop, Addis Ababa, Ethiopia, April 1963.

[24] M. Tekalign, I. Haque, and C. S. Kamara, "Phosphorus status of some Ethiopian highland Vertisols," in Proceedings of the Conference Held at the International Livestock Center for Africa, ILCA, pp. 232-252, Addis Ababa, Ethiopia, 1988.

[25] ATA, Soil Fertility Status and Fertilizer Recommendation Atlas for Tigray Regional State, Ethiopia, Agricultural Transformation Agency, Ministry of Agriculture, New Delhi, India, 2014.

[26] Ministry of Agriculture and Rural Development \& World Bank (MoA \& WB), Ethiopia, Thematic Papers on Land Degradation in Ethiopia, Ministry of Agriculture and Rural Development \& World Bank (MoA \& WB), New Delhi, India, 2007.

[27] K. Wolka, A. Moges, and F. Yimer, "Effects of level soil bunds and stone bunds on soil properties and its implications for crop production: the case of Bokole watershed, Dawuro zone, Southern Ethiopia," Agricultural Sciences, vol. 2, no. 3, pp. 357-363, 2011.

[28] L. Berry, J. Olson, and D. Campbell, Assessing the Extent, Cost and Impact of Land Degradation at the National Level: Findings and Lessons Learned from Seven PilotWorld Bank, Washington, DC, USA, 2003.

[29] A. Muluneh, B. Biazin, L. Stroosnijder, W. Bewket, and S. Keesstra, "Impact of predicted changes in rainfall and atmospheric carbon dioxide on maize and wheat yields in the Central Rift valley of Ethiopia," Regional Environmental Change, vol. 15, pp. 1105-1119, 2015.

[30] H. Hurni, "Assessing sustainable land management," Agriculture, Ecosystem and Environment, vol. 81, no. 2, pp. 83-92, 2000.

[31] P. Matous, Y. Todo, and D. Mojo, "Roles of extension and ethno-religious networks in acceptance of resource-conserving agriculture among Ethiopian farmers," International Journal of Sustainable, vol. 11, pp. 301-316, 2013.

[32] N. Haregeweyn, A. Tsunekawa, J. Nyssen et al., "Soil erosion and conservation in Ethiopia: a review," Progress in Physical Geography, vol. 39, pp. 750-774, 2015.

[33] UNIDO, Integrated Agro-Industrial Parks in Ethiopia, United Nations Industrial Development Organisation, Vienna, Austria, 2016.

[34] T. Hawando, "Desertification in Ethiopian highlands," Rala Report No. 200, pp. 75-86, Norwegian Church AID, Oslo, Norway, 1997. 
[35] K. Yenealem, B. Fekadu, J. Haji, and L. Belaineh, "Impact of integrated soil and water conservation program on crop production and income in West Harerghe zone, Ethiopia," International Journal of Environmental Monitoring and Analysis, vol. 1, no. 4, pp. 111-120, 2013.

[36] H. Hurni, "Land degradation, famines and resource scenarios in Ethiopia," in World Soil Erosion and Conservation, D. Pimentel, Ed., Cambridge University Press, Cambridge, UK, pp. 27-62, 1993.

[37] A. Million, "Characterization of indigenous stone bunding (Kab) and its effect on crop yield and soil productivity at Mesobit-Gedba, North Showa zone of Amhara region," MSc Thesis, Alemaya University, Dire Dawa, Ethiopia, 2003.

[38] H. Hurni, W. A. Berhe, P. Chadhokar et al., Soil and Water Conservation in Ethiopia: Guidelines for Development Agents, Centre for Development and Environment, Bern, Switzerland, 2016.

[39] W. Hailu, A. Moges, and F. Yimer, "The Effects of "Fanya juu" soil conservation structure on selected soil physical \& chemical properties: the case of Goromti Watershed, Western Ethiopia," Resources and Environment, vol. 2, no. 4, pp. 132-140, 2012.

[40] Z. Adimassu, K. Mekonnen, C. Yirga, and A. Kessler, "Effect of soil bunds on runoff, soil and nutrient losses, and crop yield in the central highlands of Ethiopia," Land Degradation \& Development, vol. 25, no. 6, pp. 554-564, 2014.

[41] Y. G. Selassie, F. Anemut, and S. Addisu, "Effects of land use types, management practices and slope classes on selected soil physico-chemical properties in Zikre watershed, NorthWestern Ethiopia," Environmental Systems Research, vol. 4, no. 1, p. 7, 2015.

[42] A. Challa, A. Abdelkadir, and T. Mengistu, "Effects of graded stone bunds on selected soil properties in the central highlands of Ethiopia," International Journal of Natural Resource Ecology and Management, vol. 1, no. 2, pp. 42-50, 2016.

[43] M. Dagnachew, A. Moges, A. Kebede, and A. Abebe, "Effects of soil and water conservation measures on soil quality indicators": the case of Geshy subcatchment, Gojeb river catchment, Ethiopia," Applied and Environmental Soil Science, vol. 2020, Article ID 1868792, 16 pages, 2020.

[44] D. B. Gadana, P. D. Sharma, and D. T. Selfeko, "Effect of soil management practices and slope on soil fertility of cultivated lands in Mawula watershed, loma district, southern Ethiopia," Advances in Agriculture, vol. 2020, Article ID 8866230, 13 pages, 2020.

[45] B. Woldeamlak, "Soil and water conservation intervention with conventional technologies in north- western highlands of Ethiopia: acceptance and adoption by farmers," Land Use Policy, vol. 24, no. 2, pp. 404-416, 2007.

[46] G. J. Bouyoucos, "Hydrometer method improvement for making particle size analysis of soils," Agronomy Journal, vol. 54, pp. 179-186, 1962.

[47] C. A. Black, Methods of Soil Analysis Part I, American Society of Agronomy, Madison, WI, USA, 1965.

[48] L. Van Reeuwijk, Procedures for Soil Analysis, International Soil Reference and Information Centre, Wageningen, Netherlands, 1992.

[49] A. Walkley and I. A. Black, "An examination of the degtjareff method for determining soil organic matter, and a proposed modification of the chromic acid titration method," Soil Science, vol. 37, no. 1, pp. 29-38, 1934.

[50] J. M. Bremner and C. S. Mulvaney, "Total nitrogen," in Methods of Soil Analysis. II. Chemical and Microbiological Properties, A. L. Page, R. H. Miller, and D. R. Keeney, Eds., pp. 595-624, American Society of Agronomy, Soil Science Society of America, Madison, WI, USA, 1982.

[51] S. R. Olsen, C. V. Cole, F. S. Watanabe, and L. A. Dean, Estimation of Available Phosphorus in Soils by Extraction with Sodium Bicarbonate, Allen Institute for AI, Seattle, WA, USA, 1954.

[52] H. D. Chapman, "Cation exchange capacity," in Methods of Soil Analysis, Part 2, C. A. Black, Ed., American Society of Agronomy, Madison, WI, USA, 1965.

[53] D. L. Rowell, Soil Science: Methods and Applications, Addison Wesley Longman Singapore Publishers (Pte) Ltd., England, UK, 1994.

[54] SAS, Statistical Analysis System, SAS Institute, Cary, NC, USA, 2008.

[55] Y. Mulat, "Indigenous knowledge practices in soil conservation at Konso people, south western Ethiopia," Journal of Agriculture and Environmental Sciences, vol. 2, no. 2, pp. 1-10, 2013.

[56] G. Mihrete, "Effect of soil conservation measures on some physico-chemical properties of soil and crop yield in Simada district, South Gondar zone, Ethiopia," Master's Thesis, Haramaya University, Dire Dawa, Ethiopia, 2014.

[57] M. Daniel, B. Woldeamlak, and R. Lal, "Conservation effects on soil quality and climate change," Land Degradation and Development, vol. 27, no. 6, pp. 1603-1621, 2015.

[58] Y. Yishak, T. Girma, and M. Tesfaye, "Influence of soil erosion and conservation practices on soil physical properties in Ginaberet, Ethiopia," Forest Research and Engineering: International Journal, vol. 2, no. 6, pp. 288-297, 2018.

[59] M. Guadie, E. Molla, M. Mekonnen, and A. Cerdà, "Effects of soil bund and stone-faced soil bund on soil physicochemical properties and crop yield under rain-fed conditions of northwest Ethiopia," Land, vol. 9, 2020.

[60] D. Mulugeta and S. Karl, "Assessment of integrated soil and water conservation measures on key soil properties in South Gonder, NorthWestern highlands of Ethiopia," Journal of Soil Science and Environmental Management, vol. 1, no. 7, pp. 164-176, 2010.

[61] A. Ayalew, "Construction of soil conservation structures for improvement of crops and soil productivity in the Southern Ethiopia," Journal of Environmental Sciences, vol. 1, pp. 21-29, 2011.

[62] N. Wakene, "Assessment of important physicochemical properties of nitosols under different management systems in Bako area, Western Ethiopia," MSc Thesis, Alemaya University, Dire Dawa, Ethiopia, 2001.

[63] T. Eleni, "Determinants for continued use of soil and water conservation practices: the case of productive safety net program in Tulla district, Ethiopia," Master Thesis, Wageningen University, Wageningen, Netherlands, 2008.

[64] M. Barungi and B. B. Maonga, "Adoption of soil management technologies by smallholder farmers in Central and Southern Malawi," Journal of Sustainable Development in Africa, vol. 13, no. 3, pp. 28-38, 2011.

[65] T. Tadese, "Soil, plant, water, fertilizer, animal manure and compost analysis," International Livestock Research Center, vol. 16, 1991.

[66] A. Tadele, T. Aemro, G. Yihenew, Y. Birru, W. Bettina, and H. Hurni, "Soil properties and crop yields along the terraces and toposequece of Anjeni watershed, central Highlands of Ethiopia," Journal of Agricultural Sciences, vol. 5, no. 2, pp. 134-144, 2013. 
[67] F. Itanna, "Sulfur distribution in five Ethiopian Rift valley soils under humid and semi arid climate," Journal of Arid Environments, vol. 62, pp. 597-612, 2005.

[68] FAO (Food and Agriculture Organization), Plant Nutrition for Food Security: A Guide for Integrated Nutrient Management, FAO, Fertilizer and Plant Nutrition Bulletin, Rome, Italy, 2006.

[69] P. Hazelton and B. Murphy, Interpreting Soil Test Results: What do All the Numbers Mean?, CSIRO Publishing, Clayton, Australia, 2nd edition, 2007.

[70] C. Mengistu, K. Kibebew, and F. Tarekegn, "Influence of different land use types and soil depths on selected soil properties related to soil fertility in Warandhab area, Horo Guduru Wallaga zone, Oromiya, Ethiopia," International Journal of Environmental Sciences and Natural Resources, vol. 4, no. 2, pp. 68-78, 2017. 